\title{
The Factors Affecting the Adoption of Online Banking Services by Civil Servants in Cameroon
}

\author{
Lith Enestine Tembon Ambit \\ Istanbul Aydin University \\ Institute of Graduate Studies
}

\begin{abstract}
Factors affecting the adoption of online banking services by civil servants in Cameroon was examined in this survey. Raw data were gotten through questionnaire which was distributed mostly among the civil servant in Douala of Cameroon. The analyses used in this survey were crosstabs test, descriptive analysis, factor analysis, correlation test, and regression test. The findings revealed that awareness factor has a positive and significant effect on online banking, security \& trust assurance showed a negative and insignificant effect on online banking service, innovative factor displayed a negative and insignificant effect on online banking service, and customer service assurance revealed positive but has insignificant impact on online banking service. It was concluded that internet banking is difficult to understand and its time consuming among many of the users and internet fraud discourages the use of internet banking in Cameroon. Additionally, the dissemination of information through the internet is not mostly secure and efficient.
\end{abstract}

Keywords:- Online, Banking, Customer Service, Satisfaction, and Cameroon.

\section{INTRODUCTION}

The issues affecting the use of internet services of the bank by civil servants in Cameroon cannot be overemphasized. Banks play a crucial role in the financial formulation of any nation and exhibit a substantial role in the growth and development via competent services (AlSmadi, 2012). Also, growth is one of the vital aims of the governments (Ugurlu,2009, Ugurlu,2010). Banks offer linkage between borrowers and lenders, surplus and deficit units, resulting to form investment. Some years ago, banking services have been faced with different changes connected with financial liberalization and globalization. Due to the technological changes or modernization, banks develop different choices of services accessible to the existing and potential customers and increase their reliance on technology. Banking sector is one of the inclined sectors accepting technologies which are obliging in producing improved services to clients. Technological innovations improve the quality of service and safe transaction time (Safeena, Abdullah, \& Date, 2010). Online banking uses web as a means of rending services such as funds transfer, paying bills, opening of account, buying financial instruments and the like (Haque et al. 2009 as cited by Samsunia, 2016).
The bank service delivery can be competent when the contextual processes are well-organized. An effective contextual process could be achieved when it is cohesive with electronic settings. The mechanisms such as hardware, data, app, web and customers are the crucial basics of the structure. The clients become fulfilled through service once it springs the greatest expediency and solace of service execution (Singhai \& Padhmanabhan, 2008). The swift advance of web advancement and circulation of cell phones, online banking has attracted attention in offering financial services. Online banking offers monetary transactions services like fund transfer and pay bills through cell phones device and smart phone. In looking for enhancements in client involvement, financial societies have instigated subscribing various online banking services. Online banking is a way of exploring possibility to use internet app in one of the several domains of commerce. The only way that banks could be allied to their clients at any location and time is via online applications (Singhai \& Padhmanabhan, 2008). Luo, et al. (2010) online banking offers new cost saving prospects for banks, decreasing operation costs, diminishing error in transactions and reducing fraud, producing extra revenue via commissions and service fees, and increasing retention and loyalty among customers.

Although online banking accompanies a swarm of risks and security dangers yet at the same time an everincreasing number of banks are utilizing the advantages the online needs to convey banking services to clients/customers. Banks have applied online banking to offer customers a variation of services with more suitability for accessing information and making transactions (Safeena, Abdullah, \& Date, 2010). Besides, Amin (2009) carried out an investigation and found out that issues influencing a consumer to admit or reject the practice of online banking are the deceptive usefulness, comfort of usage, and social norms were significant whiles alleged pleasure were unimportant to the adoption of online banking on consumers behave. The review conducted by other studies on the subject such as Kolodinsky et al. (2004); Pikkarainen et al. (2004); Yiua Grantc \& Edgar (2007); depict that many studies were carried out in developed countries. In contrast, few studies were carried out in developing countries such as Jabnoun and AlTamimi (2003); Al-Somali, et at. (2009).

\footnotetext{
$>$ Study Scope

The study shall mainly focus on Civil Servant in Cameroon. Cameroon is in Central Africa with area covered of about $475,650 \mathrm{~km}^{2}(183,650$ sq.mi). it has about
} 
24million population and has about 250 ethnic groups with 270 African languages and dialects. However, the commercial capital of Cameroon (Douala) will be major focused. Douala has about 1.3million people comprised of civil servant and non-civil servant. The civil servant will be majorly used as the target audience in this study.

\section{LITERATURE REVIEW}

Banks have utilized online networks to carry out banking activities with their clients. Recently, financial institutions are using online means to get guidelines and communicate services to the final consumers. Although, the scope of administrations assumed by banks about the online shift generally in element, which is known as internet banking. Online banking definition differs among scholars, according to Daniel (1999), online banking implies a sort of administrations in which clients can demand info and complete banking services via processor, TV or mobile communication. Internet banking is the exchanging of services via internet networks that includes electronic plantation and connectivity of services through electronic means. This can consolidate store enchanting, advancing, the course of action of budgetary device, electronic charge portion, and the game plan for various things and organizations, for instance, electronic money. The electronic banking as yielded a technique channel to motivate in achieving high ground and augmentation a bit of the general business. Also, electronic administrations can spare the expense of assets, which are required for customary financial administrations (Jayawardhena et al. 2000, Ugurlu, 2020). Aladwani, (2001) proposed that ebanking gives quicker, simpler and increasingly solid administrations to clients.

Electronic banking (e-banking) is a banking instruments, expected to the clients, lawfully structured/designed, which allows installment of payments, exchanging transaction, cash transaction record to another, etc. Electronic banking is utilized in connection with PC and internet, regardless of the location of the participant. Ebanking is a general term referred to characterize the specific banking services which include the use of electronic, internet and mobile technologies (Kim et al., 2011). E-banking system signifies a range of systems ranging from automated teller machines (ATMs), electronic banking, computer banking, cable banking, Online banking and, most recently, smartphone banking (Parker \& Parker, 2008). Such technologies are rapidly widespread in the banking sector and are used to offer better services to consumers seeking simplicity and technology-savvy and to minimize banks' operating costs (Nasri, 2011). Internet and mobile banking have been the leading distribution platforms used by banks to service their clients in line with customer demand and higher returns and market conditions (Moutinho \& Curry, 1994).

Alalwan, Baabdullah, Rana, Tamilmanic, and Dwivedic (2018) investigated the adoption of mobile internet in Saudi Arabia. Questionnaire was distributed to the selected elements of the population using structural equation modelling. They found that the adoption of mobile internet by Saudi customers is motivated with trust, innovativeness, perceived usefulness and enjoyment which are statistically significant. Jansen and Schaik (2018) wrote on testing online behavior in banking sector of Netherlands. Partial least square path modelling was used in the study and the results revealed that there exists high level of variance for precautionary online behavior. Jehan and Ansari (2018) conducted a survey in Saudi Arabia on the adoption of internet banking. The descriptive analysis revealed that trust is the most prominent aspect for the internet banking acceptance. Alalwana, Dwivedi, and Rana (2017) considered the influences inducing the acceptance of mobile banking by Jordanian banks where 343 respondents were participated in the survey using structural equation modelling technique. The study found out that behavioral intention exhibits significant and positive impact on the other variables used in the study. Medrad and Mohammadi (2017) wrote on the impact of word of mouth on the adoption of mobile banking in Iran, using structural equation modelling and path analysis. The findings showed that the main factor affecting mobile banking is the word of mouth. Patel and Patel (2017) used structural equation modelling to examine the adoption of internet banking in India and found that the increase in technology acceptance model inculcate higher prediction compared to banking services technology acceptance model.

Montazemi and Qahri-Saremi (2015) examined the factors affecting online banking adoption. The study employed two-stage random effects meta-analytic and structural equation modelling methods, and it revealed that ten major factors affect consumer's adoption of the ebanking. Akhisar, Tunay and Tunay (2015) wrote on innovations on the performance of banking using e-banking services as a case study in developed and developing countries. Panel data analysis was used, and the report showed that bank profitability is affected with e-banking significantly. Dauda and Lee (2015) investigated the adoption of technology and consumers' preference on online banking service in Nigeria using conjoint analysis. Their study found that the adoption of e-banking services needed to increase some factors such as ATMs integrated with smart phones, website customization, and biometric services. Shieh, Chang, Fu, Lin, and Chen (2014) examined the factor that affects the adoption of mobile services in Taiwan. Fuzzy hierarchy process model was used to analysis the gathered data and they found that mobile service is important than both mobile equipment and consumers' psychological factors.

Yiua, Grantc, and Edgar (2007) studied the factors affecting the adoption of online banking in Hong Kong. Ttest and Pearson correlation were used as the estimation techniques, and it was revealed that some factors showed positive connection with the embracing of internet banking. Cheng, Lam, and Yeung (2006) examined internet banking adoption in Hong Kong. They employed structural equation modelling as the estimation technique and found out TAM model needs to be supported and extended that what determine the behavior of the users is their intention. Shah 
and Siddiqui (2006) investigated organizational factors in adopting online banking using Woolwich bank in UK. The study employed interview form of qualitative research method, and revealed some factors affecting e-banking, some of them are customers' understanding, multiple channels, system integration, organizational flexibility, to mention a few. Bauer and Hein (2006) studied risk effect on the adoption of online banking in US, employing logistic regression as the estimation technique. However, the findings showed that educating younger customers about internet banking risk is more useful than educating older customers.

\section{Gap in the Literature}

This investigation attempts to focus on the factors affecting the adoption of internet banking services by civil servants in Cameroon. Meanwhile, the empirical reviewed above shows many investigations that have been conducted relating to the subject. However, this has not been majorly conducted in Africa continent where technology development is still the major focus in most of the countries.

\section{METHODOLOGY}

\section{Population}

The study area is Cameroon which is at the central of Africa. More than 250 native languages are spoken in the country but has two official languages such as French and English. It has about $475,442 \mathrm{~km}^{2}$ area with above 25.22million population according to World bank in 2018 . Meanwhile, civil servants are the target audience of this study and its population according to payroll list as at 2018 is above 400,000 (Ngenge, 2019).

\section{Sampling}

Sampling notes the intention of collecting data from a survey which is to enable the researcher to make assertions about the population in which the sample is conducted that focus entirely on the relationship between the target survey and the actual population. The sampling decision ought to be important in gathering the information needed. This study population is 400,000 participants though the total sample shall be selected using Yamane (1967) formula to arrive at the study sample population.

The formula is presented as:

$$
\begin{gathered}
n=\frac{N}{1+N(\mathrm{e})^{2}} \\
\text { where } n=\text { overall samaple } \\
N=\text { Population } \\
e=\text { Level of siginificance }(\text { Taken to be } 0.05) \\
n=\frac{N}{1+N(\mathrm{e})^{2}} \\
=\frac{400000}{1+400000(0.05)^{2}} \\
=399 \\
n=393 \text { Respondents }
\end{gathered}
$$

Three hundred and ninety-nine (399) questionnaires shall be used and distributed in the study. The respondents shall be selected randomly from different location of the Cameroon.

\section{Model Specification and Framework}

This study shall adapt a functional model which is presented as follows:

OBS $=\mathrm{f}(\mathrm{IF}, \mathrm{STF}, \mathrm{CSA}, \mathrm{AF}, \mathrm{U})$

Where

OBS - Online Banking Service

IF - Innovative Factor

STF - Security \& Trust Factor

CSA - Customer Service Assurance

$\mathrm{AF}$ - Awareness Factor

U - Other Factors

\section{Conceptual Framework}

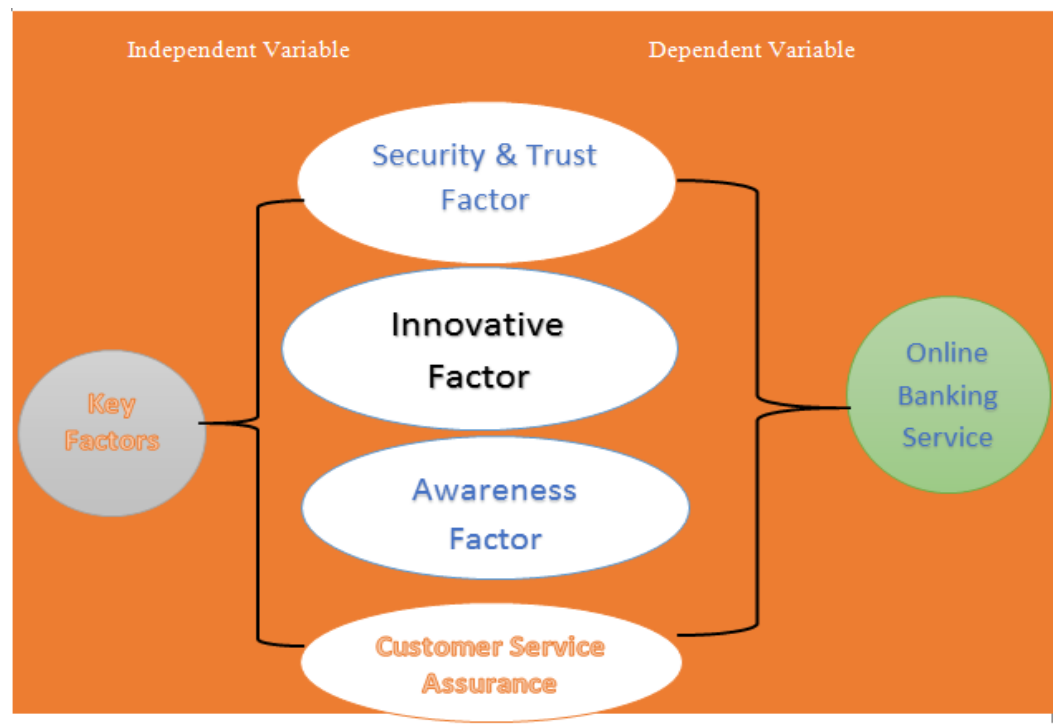

Fig 1

Source: Author's Design 
This study independent variable is the key factors which is proxy with security $\&$ trust factor, innovative factor, awareness factor, and customer service assurance while the dependent variable is online banking service.

\section{Result Presentation and Discussion}

- Crosstabs Analysis

\begin{tabular}{|c|c|c|c|c|}
\hline \multicolumn{2}{|c|}{ Count } & \multicolumn{3}{|c|}{ Total } \\
\cline { 3 - 5 } & \multicolumn{2}{|c|}{ Do you use online banking services? } \\
\hline \multirow{2}{*}{ What is your sex group? } & Male & No & 157 & 165 \\
\cline { 3 - 5 } & Female & 8 & 135 & 143 \\
\hline \multicolumn{2}{|c|}{ Total } & 16 & 292 & 308 \\
\hline
\end{tabular}

Table 1:- What is your sex group?* Do you use online banking services? Crosstabulation

Source: Researcher's computation

The above table shows the report of crosstabs test conducted between gender and the use of banking service in Cameroon. The report revealed that 8 males chose No that they did not use online banking service and 157 of the males chose yes while 8 females chose No and 143 of the females chose Yes. This indicates that many of the participants use online banking service though the male users are more than the female users.

\begin{tabular}{|c|c|c|c|c|}
\hline & & \multicolumn{2}{|c|}{ Do you use online banking services? } & \multirow[t]{2}{*}{ Total } \\
\hline & & No & Yes & \\
\hline \multirow{4}{*}{ What is your age? } & Under 18 & 4 & 20 & 24 \\
\hline & $19-25$ & 2 & 118 & 120 \\
\hline & $26-35$ & 3 & 101 & 104 \\
\hline & $36-45$ & 7 & 53 & 60 \\
\hline \multicolumn{2}{|c|}{ Total } & 16 & 292 & 308 \\
\hline
\end{tabular}

Table 1:- What is your age? * Do you use online banking services? Crosstabulation

Source: Researcher's computation

Table 2 displayed the crosstabs between age bracket of the participants and online banking service usage. It was reported that age under 18 accounted for 4 No and 20 Yes, age bracket between 19-25year accounted for 2 No and 118 Yes, age bracket between 26-35years are 3 No and 101 Yes, while age between 36-45years accounted for 7 No and 53 Yes, indicating that the age between 19-25 mostly use online banking, followed by age between 26-35years, 36-45years, and under 18 respectively.

- Descriptive Analysis

\begin{tabular}{|c|c|c|c|c|c|}
\hline & N & Minimum & Maximum & Mean & Std. Deviation \\
\hline Online Banking Service & 308 & 0 & 3 & .99 & .379 \\
\hline Awareness Factor & 308 & 0 & 3 & 1.38 & .671 \\
\hline Security \& Trust Assurance & 308 & 1 & 5 & 2.09 & .923 \\
\hline Innovative Factor & 308 & 1 & 5 & 2.08 & .837 \\
\hline Customer Service Assurance & 308 & 1 & 5 & & \\
\hline Valid N (listwise) & 308 & & & & \\
\hline
\end{tabular}

Table 3:- Descriptive Result

Source: Researcher's computation

The descriptive method revealed the minimum value of 0 for both online banking and awareness factor while security $\&$ trust assurance, innovative factor, and customer service revealed the minimum value of 1 . The maximum also showed 3 for both online banking and awareness factor with an average value of 0.99 and 1.38 respectively. The standard deviation value of online banking service and awareness are 0.379 and 0.671 . More so, the maximum value of the other variables such security $\&$ trust assurance, innovative factor, and customer service is 5 with the average value of $2.09,2.08$, and 2.19 while the standard deviation values are $0.923,0.837$, and 0.870 respectively. 
- Reliability Result

\begin{tabular}{|c|c|}
\hline Cronbach's Alpha & N of Items \\
\hline .768 & 12 \\
\hline
\end{tabular}

Table 4:- Reliability Statistics

Source: Researcher's computation

The report of the reliability test shows the value of 0.768 on the questionnaires distributed to the participants which indicates that the questionnaire has above 75 percent reliability to capture the study focus.

\section{- Factor Analysis}

\begin{tabular}{|c|c|c|c|c|c|c|}
\hline \multirow{2}{*}{ Component } & \multicolumn{3}{|c|}{ Initial Eigenvalues } & \multicolumn{3}{c|}{ Extraction Sums of Squared Loadings } \\
\cline { 2 - 7 } & Total & \% of Variance & Cumulative \% & Total & \% of Variance & Cumulative \% \\
\hline 1 & 6.697 & 55.812 & 55.812 & 6.697 & 55.812 & 55.812 \\
\hline 2 & .926 & 7.717 & 63.529 & & & \\
\hline 3 & .711 & 5.929 & 69.458 & & & \\
\hline 4 & .672 & 5.599 & 75.056 & & & \\
\hline 5 & .622 & 5.179 & 80.236 & & & \\
\hline 6 & .523 & 4.358 & 84.594 & & & \\
\hline 7 & .410 & 3.414 & 88.008 & & & \\
\hline 8 & .374 & 3.117 & 91.125 & & & \\
\hline 9 & .339 & 2.821 & 93.946 & & & \\
\hline 10 & .300 & 2.497 & 96.443 & & & \\
\hline 11 & .233 & 1.940 & 98.384 & & & \\
\hline
\end{tabular}

Table 5:- Total Variance Explained

Source: Researcher's computation

The variational factor analysis employed in the survey using the sum extraction loadings revealed that the first component has the value of 55.812 representing 55.8percent which indicates that the first component could accounted for more than 50percent in the items.

\section{- Correlation Result}

\begin{tabular}{|c|c|c|c|c|c|c|}
\hline & & $\begin{array}{c}\text { Online } \\
\text { Banking } \\
\text { Service }\end{array}$ & Awareness Factor & $\begin{array}{c}\text { Security \& Trust } \\
\text { Assurance }\end{array}$ & Innovative Factor & $\begin{array}{l}\text { Customer } \\
\text { Service } \\
\text { Assurance }\end{array}$ \\
\hline \multirow{3}{*}{$\begin{array}{c}\text { Online Banking } \\
\text { Service }\end{array}$} & Pearson Value & 1 & $.343^{* *}$ & -.101 & $-.153^{* *}$ & -.046 \\
\hline & Sig. & & .000 & .077 & .007 & .423 \\
\hline & $\mathrm{N}$ & 308 & 308 & 308 & 308 & 308 \\
\hline \multirow{3}{*}{ Awareness Factor } & Pearson Value & $.343^{* *}$ & 1 & $-.297^{* *}$ & $-.345^{* *}$ & $-.265^{* *}$ \\
\hline & Sig. & .000 & & .000 & .000 & .000 \\
\hline & $\mathrm{N}$ & 308 & 308 & 308 & 308 & 308 \\
\hline \multirow{3}{*}{$\begin{array}{c}\text { Security \& Trust } \\
\text { Assurance }\end{array}$} & Pearson Value & -.101 & $-.297^{* *}$ & 1 & $.556^{* * *}$ & $.559^{* * *}$ \\
\hline & Sig. & .077 & .000 & & .000 & .000 \\
\hline & $\mathrm{N}$ & 308 & 308 & 308 & 308 & 308 \\
\hline \multirow{3}{*}{ Innovative Factor } & Pearson Value & $-.153^{* *}$ & $-.345^{* *}$ & $.556^{* *}$ & 1 & $.503^{\text {** }}$ \\
\hline & Sig. & .007 & .000 & .000 & & .000 \\
\hline & $\mathrm{N}$ & 308 & 308 & 308 & 308 & 308 \\
\hline \multirow{3}{*}{$\begin{array}{c}\text { Customer Service } \\
\text { Assurance }\end{array}$} & Pearson Value & -.046 & $-.265^{* *}$ & $.559^{* *}$ & $.503^{* *}$ & 1 \\
\hline & Sig. & .423 & .000 & .000 & .000 & \\
\hline & $\mathrm{N}$ & 308 & 308 & 308 & 308 & 308 \\
\hline
\end{tabular}

Table 6:- Correlations

Source:- Researcher's computation

Table 6 presented the correlation result among the variables employed in the survey. The report reveals that online banking and awareness factor has the value of 0.343 with sig value of 0.000 , indicating that positive and significant connection exists between online banking service and awareness factor. The connection between online banking service and security \& trust 
assurance has the value of -0.101 with significant value of 0.077 showing that negative and insignificant connection exists between online banking and security \& trust assurance. The correlation between online and innovative factor has the value -0.153 with significant value of 0.007 , indicating that negative and significant connection exists between online banking and innovator factor. Also, the connection between online banking and customer service assurance shows that value of -0.046 with significant value of 0.423 , implying that negative and insignificant relationship exists between online banking service and customer service assurance during the study period.

- Regression Result

\begin{tabular}{|c|c|c|c|c|c|c|}
\hline \multicolumn{2}{|c|}{} & Sum of Squares & df & Mean Square & F & Sig. \\
\hline \multirow{4}{*}{} & Regression & 5.457 & 4 & 1.364 & 10.729 & .000 \\
\cline { 2 - 7 } & Residual & 38.530 & 303 & .127 & & \\
\cline { 2 - 8 } & Total & 43.987 & 307 & & &
\end{tabular}

Table 7:- Analysis of Variance

Source: Researcher's computation

The table above shows the analysis of variance result of regression showing the regression and residual values of 5.457 and 38.530 with the degree of freedom value of 4 and 303. The mean square values are 1.364 and 0.127 . Meanwhile, the F-stat and its significant values are 10.729 and 0.000 . this indicates the control variables could influence the dependent value (online banking service).

\begin{tabular}{|c|c|c|c|c|c|}
\hline \multirow{2}{*}{$\begin{array}{c}\text { Dependent Variable: Online Banking } \\
\text { Service }\end{array}$} & \multicolumn{2}{|c|}{ Unstandardized Coefficients } & \multirow{2}{*}{$\begin{array}{c}\text { Standardized } \\
\text { Coefficients } \\
\text { Beta } \\
\end{array}$} & \multirow[t]{2}{*}{$\mathrm{t}$} & \multirow[t]{2}{*}{ Sig. } \\
\hline & $\mathrm{B}$ & Std. Error & & & \\
\hline (Constant) & .727 & .093 & & 7.823 & .000 \\
\hline Awareness Factor & .190 & .033 & .338 & 5.828 & .000 \\
\hline Security \& Trust Assurance & -.002 & .029 & -.006 & -.084 & .933 \\
\hline Innovative Factor & -.034 & .031 & -.076 & -1.101 & .272 \\
\hline $\begin{array}{c}\text { Customer Service } \\
\text { Assurance }\end{array}$ & .037 & .029 & .085 & 1.255 & .210 \\
\hline
\end{tabular}

Table 8:- Coefficients

Source: Researcher's computation

Table 8 reveals that coefficient of the variables used in this survey. The reliant variable is the online banking service against the control variables which includes awareness factor, security \& trust assurance, innovative factor, and customer service assurance. The report shows that awareness factor has the coefficient figure of 0.190 with standard error 0.033 and sig value of 0.000 , implying that positive and significant effect exists between online banking and awareness factor, that is, when awareness factor is employed, there will be a positive and significant impact on online banking services. Security \& trust assurance shows the coefficient value of -0.002 with standard error of 0.029 and the sig value of 0.933 indicating that security \& trust assurance reveal a negative and insignificant effect on online banking service and this could be as a result of the limited technological measures in monitoring the online activities in most of the developing countries of the world. The coefficient figure of innovative factor displayed was -0.034 with standard error value of 0.031 and sig figure of 0.272 , indicating a negative and insignificant effect on online banking service that is, innovative factor revealed negative impact on online banking. The customer service assurance coefficient value is 0.037 with standard error of 0.029 and sig figure of 0.210 , implying that customer service assurance reveals positive but has insignificant impact on online banking service.

\section{CONCLUSION \& KEY RECOMMENDATIONS}

Online banking protection can't be assured by technological solutions alone, the human element is also essential. If online banking clients don't take measures, internet banking security can be easily exploited. It is on this note this survey concluded that online services have truly changed the banking structure and interaction in Cameroon though they mostly operate it fairly. It was also concluded that information content of the online banking service is fairly good, and the awareness of the online banking service is moderate including the quality of the service is fair. Furthermore, it was concluded that the rules and regulations introduced by the regulatory authorities is not adequately encourage the online banking involvement and this makes some of the customers to be worried with online banking due to assessment of their account by other people and many of the them concur that buying goods through the online banking platform is time waste, difficult and costly in Cameroon. More so, it was also concluded that there is a positive and significant connection exists between online banking service and awareness factor, though a negative and insignificant connection exists between online banking service and security \& trust assurance, and between online banking and customer service assurance. 
$>$ Key Recommendations

In line with the findings and conclusion of the study,

following recommendations are made:

- That the government should further introduce measures through the relevant regulatory authorities to adequately encourage the online banking involvement among civil servants.

- That government and the internet providers should strength connectivity to ease assess of buying goods and other payments through the online banking platform to avoid time waste, difficult and disruption among users.

- That the banks should make a constant awareness of internet banking and should be made simple to be understood and friendly to the older customers in Cameroon

- That banks and other regulatory authorities should enhance the improvement of security $\&$ trust in order to upsurge financial inclusion and customer service assurance and satisfaction.

\section{REFERENCES}

[1]. Akhisar, I., Tunay, K. B. \& Tunay, N. (2015). The Effects of Innovations on Bank Performance: The Case of Electronic Banking Services. Procedia Social and Behavioral Sciences 195, 369 - 375.

[2]. Alalwana, A. A., Dwivedi, Y. K., \& Rana, N. P. (2017). Factors influencing adoption of mobile banking by Jordanian bank customers: Extending UTAUT2 with trust. International Journal of Information Management, 37, 99-110.

[3]. Alalwan, A. A., Baabdullah, A. M., Rana, N. P., Tamilmanic, K., \& Dwivedic, Y. K. (2018). Examining adoption of mobile internet in Saudi Arabia: Extending TAM with perceived enjoyment, innovativeness and trust. Technology in Society 55, $100-110$.

[4]. Al-Smadi, M. O. (2012). Factors Affecting Adoption of Electronic Banking: An Analysis of the Perspectives of Banks' Customers. International Journal of Business and Social Science, 3(17), 294309.

[5]. Al-Somali, S. A., Gholami, R. \& Clegg, B. (2009). An investigation into the acceptance of online banking in Saudi Arabia. Technovation, 29, 130-141.

[6]. Bauer, K. \& Hein, S. E. (2006). The effect of heterogeneous risk on the early adoption of Internet banking technologies. Journal of Banking \& Finance 30, 1713-1725.

[7]. Cheng, T. C., Lam, D. Y., \& Yeung, A. C. (2006). Adoption of internet banking: An empirical study in Hong Kong. Decision Support Systems, 42, 15581572.

[8]. Dauda, S. Y. \& Lee, J. (2015). Technology adoption: A conjoint analysis of consumers' preference on future online banking services. Information Systems, 53, 115.

[9]. Jehan, S. N., \& Ansari, Z. A. (2018). Internet Banking Adoption in Saudi Arabia: An Empirical Study. International Journal of Marketing Studies, 10(3), 57-72.
[10]. Kolodinsky, J., M., Hogarth, J., M., Hilgert, M., A., (2004). The adoption of electronic banking technologies by US consumers. The International Journal of Bank Marketing, 22(4), 238-259.

[11]. Jabnoun, N. \& Al-Tamimi, H. A. (2003). Measuring perceived service quality at UAE commercial banks. International Journal of Quality \& Reliability Management, 20, 458-472

[12]. Luo, X., Li, H., Zhang, J., \& Shim, J. P. (2010). Examining Multi-dimensional Trust and Multi-faceted Risk in Initial Acceptance of Emerging Technologies: An Empirical Study of Mobile Banking Services. Decision Support Systems, 49(2), 222-234.

[13]. Medrad, D. \& Mohammadi, S. (2017). Word of Mouth impact on the adoption of mobile banking in Iran. Telematics and Informatics 34, 1351-1363

[14]. Montazemi, A. R. \& Qahri-Saremi, H. (2015). Factors affecting adoption of online banking: A metaanalytic structural equation modelling study. Information \& Management 52, 210-226.

[15]. Moutinho, L. \& Curry, B. (1994). Consumer perception of ATMs: an application of neutral networks. Journal of Marketing Management, 10(1/3), 191-206.

[16]. Nasri, W. (2011). Factors influencing the adoption of Internet banking in Tunisia, International Journal of Business and Management, 6, 143-160.

[17]. Ngenge, S. T. (2019). Cameroon Public Administration: Civil Servants Involvement in Politics and the Impact on State Performance. International Journal of Research and Innovation in Social Science, 3(1), 243-248.

[18]. Parker, T. \& Parker, M. (2008). Electronic banking in Finland and the effect on money velocity. Journal of Money, Investment and Banking, 4, 20-25.

[19]. Patel, K. J. \& Patel, H. J. (2017). Adoption of internet banking services in Gujarat. International Journal of Bank Marketing, 36(1), 147-169.

[20]. Pikkarainen, T., Pikkarainen, K., Karjaluoto, H. \& Pahnila, S. (2004). Consumer acceptance of online banking: An extension of the technology acceptance model. Internet Research, 14(3), 224-235.

[21]. Safeena, R., Abdullah, K., \& Date, H. (2010). Customer Perspectives on E-business Value: Case Study on Internet Banking. Journal of Internet Banking and Commerce, 15(1), 1-13.

[22]. Samsunia, A. (2016). Adoption of Internet Banking: An Empirical Study in Chennai. Intercontinental Journal of Finance Research Review, 4(1), 24-30.

[23]. Shah, M. H. \& Siddiqui, F. A. (2006). Organisational critical success factors in adoption of e-banking at the Woolwich bank. International Journal of Information Management, 26, 442-456.

[24]. Singhai, D. \& Padhmanabhan, V. (2008). A Study on Customer Perception Towards Internet Banking: Identifying Major Contributing Factors. The Journal of Nepalese Business Studies, 5(1), 101-111.

[25]. Ugurlu, E. (2009), Real Exchange Rate And Economic Growth: Turkey, Manas University Social Sciences Journal, 22, 2009, pp.191-212 
[26]. Ugurlu, E. (2010), Growth and openness relationship in The EU-15: Panel data analysis, Ekonomika, Vol. 89 No. 2, pp. 44-54.

[27]. Uğurlu, F. S. (2020) Did the 2008 global financial crisis affect the banking credits? A Case of Regions of Turkey, International Journal of Humanities and Social Development Research, Volume 4, No. 1, 2020, 74-82 DOI: 10.30546/2523-4331.2020.4.1.74

[28]. Vatanasombut, B., Igbaria, M., Stylianou, A. C. \& Rodgers, W. (2008). Information Systems continuance intention of web-based applications customers: The case of online banking. Information \& Management, 45(7), 419-428.

[29]. Yiua, C. S., Grantc, K. \& Edgar, D. (2007). Factors affecting the adoption of Internet Banking in Hong Kong-implications for the banking sector. International Journal of Information Management 27, 336-351. 